\title{
CLINICAL ASPECTS OF FOOD ALLERGY IN INFANTS IN PLEVEN REGION, BULGARIA
}

\author{
Vanya M. Nedkova-Milanova, \\ Tsvetelina V. Miteva, \\ Darina N. Hristova ${ }^{1}$, \\ Lyubomira D. Gadjelova, \\ Magdalena I. Balashkova
}

Division of General Medicine, Medical University - Pleven, Bulgaria

${ }^{1}$ Department of Hygiene, Medical University - Varna, Bulgaria

\section{Corresponding Author:}

Vanya M. Nedkova-Milanova Division of General Practice, Medical University - Pleven 1, Sv. Kliment Ohridski Str.

Pleven5800,

Bulgaria

e-mail:vania_milanova@yahoo.com

Received: January 18, 2018

Revision received: May 21, 2018

Accepted: June 26, 2018

\section{Summary}

Food allergy is an immunoglobulin E-meditated reaction, to which the organism's immune system reacts to a food allergen, recognizing it as harmful. The study aimed to establish at what age cow's milk protein allergy is manifested and determine the values of immunoglobulin E (IgE) and hemoglobin( $\mathrm{Hb})$ in children with CMPA in Pleven region, Bulgaria. The study included 94 infants presenting with clinical manifestations of food allergy (age range 0 to 12 months) from Pleven and Pleven region, consulted in 2017 by a pediatrician at the University Hospital Consulting Center in Pleven. Venous blood was collected to determine the IgE and $\mathrm{Hb}$ values. Chronic iron-deficiency anemia could be the only clinical manifestation in children with CMPA. Out of all the children with CMPA, 17\% had a pronounced anemic syndrome. The rest had normal $\mathrm{Hb}$ values. Anemic syndrome could have severe consequences for a growing child. Elevated IgE values were found in $73 \%$ of the children tested. CMPA is frequently seen in infants. Early diagnosis of clinical manifestations and diet could prevent severe complications of allergy such as chronic diarrhea, chronic urticaria, and asthma.

Key words: food allergy, clinical manifestation, infants

\section{Introduction}

Food allergy is an immunoglobulin E (IgE)meditated reaction, in which the organism's immune system reacts to a food allergen, recognizing it as harmful. Some individuals, especially children under three years of age, have a genetic predisposition towards atopic illnesses and show an increased tendency towards developing food allergies $[1,2]$. The frequency of atopy decreases with the increase of age, and older children and adults develop inhalation allergies more frequently.

Animal proteins, egg whites, cow's milk, fish, seafood, soy, wheat, chocolate and nuts (almonds, peanuts) are among the leading 
allergens in early childhood [3-5]. Cow's milk protein allergy (CMPA) is the most common food allergy in infants. The diagnosis is usually made during the first 12 months after birth [69]. The symptoms involve the skin, and the gastrointestinal and respiratory tracts. IgEmediated reactions are often of sudden onset and manifest as urticaria, angioedema, anaphylaxis, bronchospasm, atopic dermatitis, acute vomiting, gastroesophageal reflux, and diarrhea or constipation (Table 1). Early recognition and prompt intervention are needed to restore normal growth and development in infants [2-5, 8].

Table 1. Symptoms of CMPA

\begin{tabular}{ll}
\hline Organ involvement & Symptoms \\
\hline Gastrointestinal tract & Infantile colic, irritable \\
& Vomiting \\
& Regurgitation \\
& Constipation \\
& Blood in stool, iron deficiency anemia \\
& Unstable defecation \\
\hline Skin & Atopic dermatitis \\
& Urticaria \\
& Angioedema \\
\hline Respiratory tract & Chronic cough \\
& Wheezing, bronchospasm \\
\hline
\end{tabular}

The purpose of the study was to find out at what age the manifestations of cow's milk protein allergy occur and to determine $\operatorname{IgE}$ and $\mathrm{Hb}$ values in children with CMP in Pleven region, Bulgaria.

\section{Material and Methods}

Study group included 94 infants aged 0-12 months from Pleven and the region, who were referred by pediatricians to the University Hospital Consulting Center in 2017 on account of clinical manifestations of food allergy. Venous blood was collected to determine the
$\mathrm{IgE}$ and $\mathrm{Hb}$ values in allergic children. Inclusion criteria were as follows:

age -0 to 12 months;

clinical manifestation of food allergy;

lack of congenital disease(s);

informed consent of parents.

The data obtained were processed with Microsoft Excel and Statgraphics for Windows XP.

\section{Results}

Out of all the surveyed children, 54\% $(n=53)$ were boys and $46 \%(n=43)$ were girls (Figure 1).

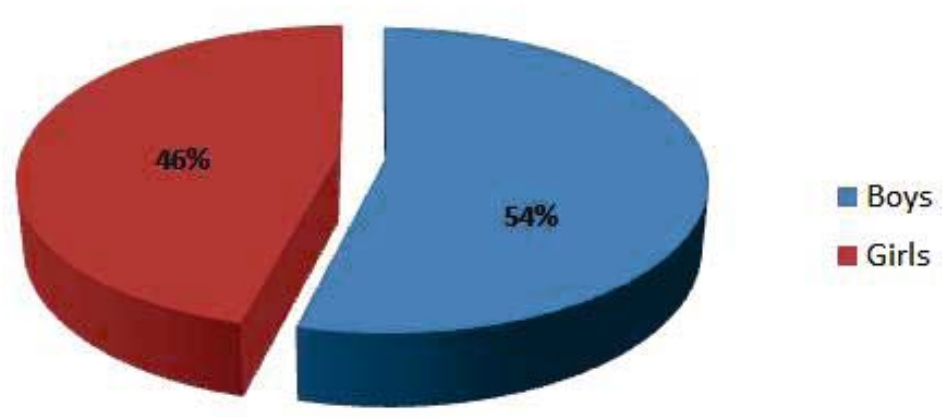

Figure 1. Gender distribution of infants with food allergy (\%) 
CMPA occured in the first 2-3 months after birth in the children studied. The mean age of onset of CMPA in our group was three months.

Most of the children with CMPA (61\%)

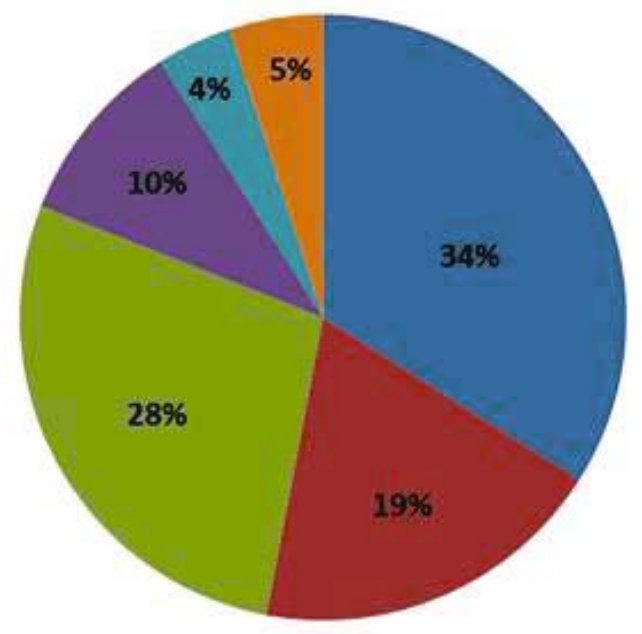

had clinical symptoms of gastrointestinal tract problems, and $34 \%$ had dermatitis. Children with bronchial obstruction were 5\% (Figure 2).

Figure 2. Clinically manifested problems in children with CMPA (\%)

Chronic iron-deficient anemia could be the only clinical manifestation in children with CMPA. Of all the children with CMPA, 17\% had a pronounced anemic syndrome. The rest had normal values of hemoglobin. (Figure 3).

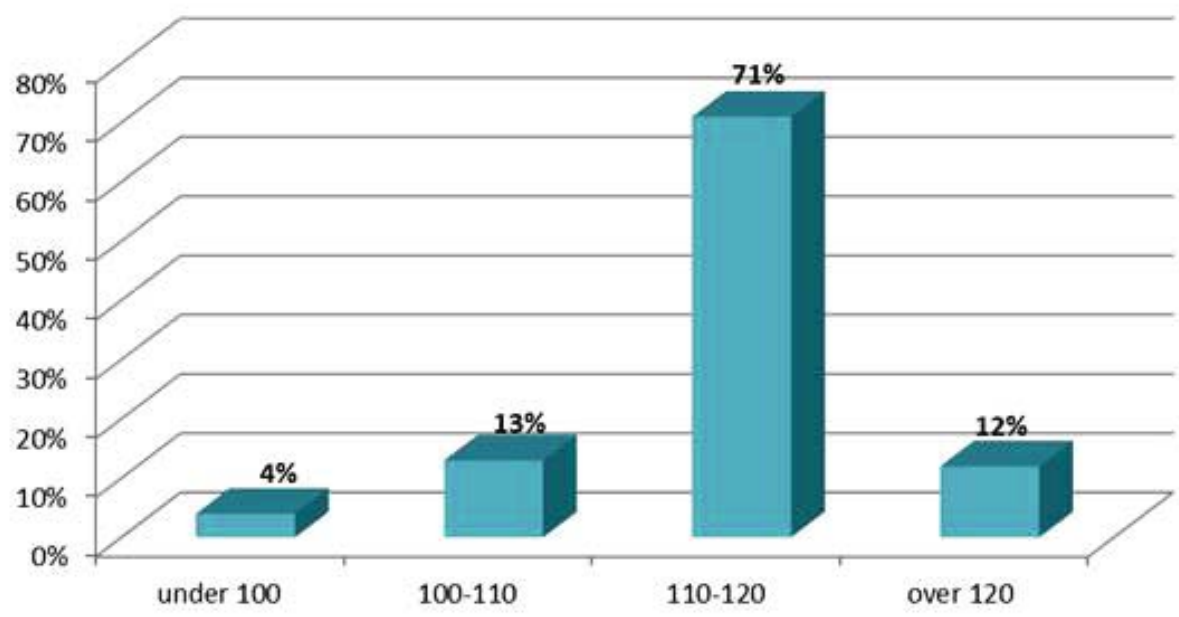

Figure 3. Distribution of infants with CMPA according to hemoglobin values (\%)

Elevated $\operatorname{IgE}$ values were found in $73 \%$ of the tested children with an average value of $36.5 \mathrm{IU} /$ $\mathrm{ml}$ (value range 18 to $115.6 \mathrm{IU} / \mathrm{ml}$ - IgEmediated allergy) - Figure 4. 


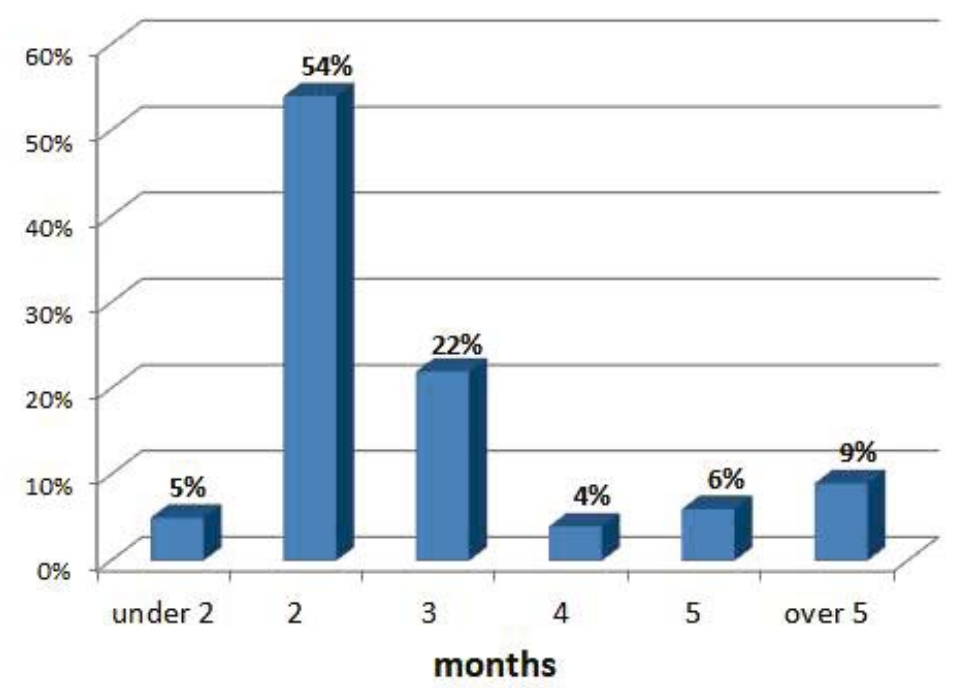

Figure 4. Distribution of infants by IgE values

\section{Discussion}

Problems related to the skin and the gastrointestinal and the respiratory tracts are the most common clinical manifestations of allergy among infants [5, 7]. An elimination diet is crucial in diagnosing allergy to cow's milk protein. The reduction of clinical manifestations of allergy after removing cow's milk from the diet and their recurrence after a provocation is a definite sign of the allergy [8]. CMPA can be IgE-mediated and non-IgE-mediated. IgEmediated allergy has a rapid onset - from 20 minutes to two hours. Laboratory tests showing elevated levels of specific IgE antibodies in the blood confirm the diagnosis and serve as a prognostic sign of prolonged allergy [8-10]. The high levels of IgE we found in 2- and 3-monthold children with cow's milk allergy increases the risk of allergy to other foods.

Non-IgE-mediated allergy has a slower onset. This allergy is more often manifested with gastrointestinal problems such as gastroenterocolitis. This allergy is more difficult to diagnose due to cellular or a mixed immune response [9-13].

All children diagnosed with CMPA were put on an elimination diet and were fed to protein hydrolyzate. The duration of the elimination diet period depended on the age, severity of the clinical symptoms, as well as on the results from the investigation for specific $\operatorname{IgE}$ antibodies [13, $14]$.
Some authors recommend that the provocation test be repeated after at least three months after of removing cow's milk proteins in cases of mild clinical manifestations and a negative test for specific IgE antibodies. However, they recommend at least a one-year elimination diet in children with high levels of specific IgE antibodies and severe allergic reactions [1518]. We recommended that the children we investigated be on an elimination diet until they completed the age of 12 months.

If the second provocation test proves positive, a strict diet without milk proteins is advisable for six months to 12 months. If the control test with provocation shows the development of tolerance, cow's milk is introduced into the child's diet. Cow's milk protein is gradually introduced into the diet with careful monitoring of the symptoms [1, 14-16]. Provocative diets are administered in the absence of symptoms and the exclusion of treatment with antihistamines. When children have a history of a recent anaphylactic reaction to cow's milk, they should undergo an elimination diet up to 12 months of age, and then a provocation test is done in a hospital setting. If the child has no clinical manifestations, cow's milk is introduced into the child's menu.

\section{Conclusions}

In recent years, the incidence of cow's milk protein allergy in infants has been rising. Early diagnosis of clinical manifestations and 
a dietary regime could prevent severe allergy complications - chronic diarrhea, chronic urticaria, and asthma. Elimination of the leading allergens from the infants' diet is the leading principle of treatment for children with such allergy.

\section{Acknowledgements}

This study was not supported by any funding source. We wish to thank Medical University Pleven.

\section{References}

1. Caffarelli C, Baldi F, Bendandi B, Calzone L, Marani M, Pasquneli P. Cow's milk protein allergy in children: a practical guide. Ital J Pediatr. $2010 \mathrm{Jan} ; 36: 5$.

2. Morita H, Nomura I, Matsuda A, Saito H, Matsumoto K. Gastrointestinal food allergy in infants. Allergol Int. 2013;62(3):297-307.

3. Werfel T, Breuer K. Role of food allergy in atopic dermatitis. Curr Opin Allergy Clin Immunol. 2004;4(5):379-85.

4. Wood RA. The natural history of food allergy. Pediatrics. 2003;111(3):1631-7.

5. Longo G, Berti I, Burks AW, Krauss B, Barbi E. IgE-mediated food allergy in children. Lancet. 2013;382(9905):1656-64.

6. Nowak-Wegrzyn A, Sampson HA, Wood RA, Sicherer SH. Food protein induced enterocolitis syndrome caused by solid food proteins. Pediatrics. 2003;111(4):829-35.

7. Ravelli AM, Tobanelli P, Volpi S, Ugazio AG. Vomiting and gastric motility in infants with cow's milk allergy. J Pediatr Gastroenterol Nutr. 2001;32(1):59-64.

8. Lifschitz C, Szajewska H. Cow's milk allergy: evidence-based diagnosis and management for the practitioner. Eur J Pediatr. 2015;174(2):14150.
9. Zeiger RS. Food allergen avoidance in the prevention of food allergy in infants and children. Pediatrics. 2003;111(3):1662-71.

10. Vandenplas Y, Alarcon P, Alliet P, De Greef E, De Ronne N, Hoffman I, et al. Algorithms for managing infant constipation, colic, regurgitation and cow's milk allergy in formula-fed infants. Acta Pediatr. 2015;104(5):449-57.

11. Nocerino R, Granata V, Di Costanzo M, Pezzella V, Leone L, Passariello, A et al. Atopy patch tests are useful to predict oral tolerance in children with gastrointestinal symptoms related to non-IgE-mediated cows milk allergy. Allergy. 2013;68(2):246-8.

12. Caubet JC, Szajewska H, Shamir R, Wegrzyn A. Non-IgE-mediated gastrointestinal food allergies in children. Pediatr Allergy Immunol. 2017;28(1):6-17.

13. Sicherer SH. Clinical aspects of gastrointestinal food allergy in childhood. Pediatrics. 2003;111(3):1609-16.

14. Koletzko S, Niggemann B, Arato A, Dias JA, Heuschkel R, Husby S, et al. Diagnostic approach and management of cow's milk protein allergy in infants and children: ESPGHAN GI Committee practical guidelines. J Pediatr Gastroenterol Nutr. 2012;55(2):221-9.

15. Vandenplas Y, Bhatia J, Shamir R, Agostoni C, Turck D, Staiano A, et al. Hydrolyzed formulas for allergy prevention. J Pediatr Gastroenterol Nutr. 2014;58(5):549-52.

16. Høst A. Frequency of cow's milk allergy in childhood. Ann Allerg Asthma Immunol. 2002;89(6 Suppl 1):S33-7.

17. Niggemann B, Beyer K. Diagnosis of food allergy in children: toward a standardization of food challenge. J Pediatr Gastroenterol Nutr. 2007;45(4):399-404.

18. Sampson HA, Anderson JA. Summary and recommendations: classification of gastrointestinal manifestations due to immunologic reactions to foods in infant and young children. J Pediatr Gastroenterol Nutr. 2000;30(Suppl):S87-94. 